wealth so won in the shape of a royalty. This system is often described as a mineral lease, but the term is misleading, because a mineral deposit is a wasting asset, and cannot therefore be leased in the true sense of the word, which implies that the lessee should return his property to the lessor in unimpaired good condition at the expiry of the period of lease. The system may be more correctly described as a sale of the minerals as and when extracted, the purchase consideration taking the form of an annual royalty payment.

The other principle, adopted by the United States and by ourselves, is that of out-and-out alienation, from the very commencement, of the mineral deposit. With us this process of alienation has long been completed; in the United States it is still proceeding as fast as mineral deposits are discovered. The mode of tenure of the mineral deposits being, however, essentially the same, the greater part of Mr. Smith's remarks are perfectly applicable to conditions in this country. His point of view is indicated by two apt quotations, one from Gen. Halleck, who wrote in 1860 , to the effect that mines "are by nature public property, and that they are to be used and regulated in such a way as to conduce most to the general interest of society." He also quotes Dr. R. W. Raymond, who, it may be remembered, gave evidence as to the American system of dealing with mineral lands before our 1889 Royal Commission on Mining Royalties, in which he showed that the policy which the United States had adopted, as best calculated to promote the national welfare, was "to get its mineral lands as soon as possible into private hands," and the quotation from Dr. Raymond's first report on mineral resources, written in 1868 , is so particularly applicable to British conditions, and deserves so well the careful consideration of all interested-and who is not?-in our mineral resources, as to deserve reproduction here :-

"In view of these peculiar relations of mining, it is evident that Governments are, in a certain sense, trustees of the wealth stored in the mineral deposits of their realms-trustees for succeeding generations of their own citizens and for the world at large. It is not a matter of indifference to the citizens of this country whether our mining fields be ravaged and exhausted in one or even five centuries, when they might last a score."

At a moment like this, when we stand at the beginning of what promises to be an industrial struggle even more keen and bitter than the actual warfare to which we are now devoting all our national energies, those responsible for the government of Great Britain would assuredly do well to take some account of the huge wastage of our own national resources that is going on unchecked and almost unheeded, and to ask themselves with what measure of fidelity they are discharging their trusteeship.

Mr. Smith lays much stress upon the development that has taken place in every portion of the American mineral industry within the past thirty-three years, and upon the fact that the utilisation of these resources has resulted in a "higher standard of public service" by "giving all the workers a better opportunity to live a full life," this being, as he justly observes, "the ideal of democracy." $\mathrm{He}$ is a firm believer in the advantage of the system of alienation of mineral lands; as he says: "Both the past record and the present status of the mining industry show that the mineral resources of the United States possess largest public value in their indireot contribution to national development. ... In fact, it may be easily shown that the State or nation will not be so much bene- fited through a direct royalty as through the indirect revenue gained by the establishment of a new industry, and by its influence on the neighbouring agricultural areas and the transportation systems to which the new traffic is tributary." $\mathrm{He}$ points out in some detail that the most equitable, as well as the most convenient, method of obtaining a direct return for the nation from its mineral wealth is by means of an income tax upon the profits realised by the miner; yet, as he is careful to add, "the public's direct share of the proceeds from mineral resources must not be so great as to affect unfavourably labor's opportunity or capital's incentive."

Few short asticles have appeared within recent years that will better repay careful study by legislators and economists than will the article now before us. It needs neither justification nor corroboration; yet were such required, they may be found in most emphatic form in the statistical summary of the mineral production of the United States in 1914, issued simultaneously. To take only a few items, the production of the principal metals was :-

$\begin{array}{llcc}\text { Pig iron } & \ldots & \ldots & 22,263,263 \text { tons } \\ \text { Copper } & \ldots & \ldots & 1,150,137,192 \mathrm{lb} . \\ \text { Lead } & \ldots & \ldots & 512,994 \text { short tons } \\ \text { Zinc } & \ldots & \ldots & 343,418 \% ", \\ \text { Nickel } & \ldots & \ldots & 845,334 \mathrm{lb} . \\ \text { Gold } & \ldots & \ldots & 4,572,976 \mathrm{oz} . \\ \text { Silver } & \ldots & \ldots & 72,455,100, "\end{array}$

Amongst non-metallic minerals the most important are coal, of which the total output was $513,525,477$ short tons, and petroleum, with a production of $265,762,535$ barrels. The total value of the mineral production of the United States is given as the enormous sum of nearly 2 I I 5 millions of dollars (say about $440,000,000 l$.), amounting to 21.40 dollars (say 4l. Ios.) per head of the population; the latter has practically doubled since 1880 , whilst the value of the mineral production has increased nearly sixfold. It would be difficult to show such vast progress in any other similar field of human industry, and, though due in the first place to the wonderful natural resources of the United States, credit must also be given to the enlightened spirit in which these resources have been utilised. Our conditions in this country are, of course, widely different, yet there is no reason why we too should not strive to utilise what we have to the uttermost. Our need in this country is to realise and act upon the counsel which Mr. Smith embodies in one brief sentence: "The governmental duty to the mining industry first of all is to promote use without waste." H. L.

\section{THE SMOKE NUISANCE IN THE} UNITED STATES.

IKE ourselves, the industrial centres of the United States are beginning to realise the serious economic and hygienic effects caused by the unscientific combustion of coal. In the Journal of the Franklin Institute for March, Dr. W. F. M. Goss has contributed a paper on "Smoke as a Source of Atmospheric Pollution," in which he discusses the results of a very elaborate investigation, extending over six years, into the consumption of coal and loss in the form of smoke in the city of Chicago, an inquiry undertaken under the auspices of the Chicago Association of Commerce.

He begins by summarising the general results of previous observers in regard to the effect of smoke on health, on vegetation, and on the loss and damage to property, and then proceeds to discuss in detail the sources of industrial smoke in Chicago and the extent of wastage.

No. 2438 , VOL. 97$]$ 
The amount of fuel (excluding liquid fuel) consumed annually in the industrial area of the city is estimated at about $I 7 \frac{1}{2}$ million tons, and includes anthracite, coke, and bituminous coal, the last representing nearly one-half of the total. The following figures are given, though, as all experimental details are omitted, it is impossible to comment on the method by which they have been ascertained :-

\begin{tabular}{|c|c|c|c|c|}
\hline Source & $\begin{array}{l}\text { Coal con- } \\
\text { sumed, tons }\end{array}$ & $\begin{array}{l}\text { Average } \\
\text { loss per } \\
\text { cent. }\end{array}$ & $\begin{array}{l}\text { Loss in } \\
\text { tons }\end{array}$ & $\begin{array}{l}\text { Percentage } \\
\text { of total los: }\end{array}$ \\
\hline Steam locomotives & $2,099,044$ & $1 \cdot 084$ & 22,750 & $7 \cdot 47$ \\
\hline $\begin{array}{l}\text { Steam vessels } \ldots \\
\text { Hijuh - pressure boilers }\end{array}$ & 81,375 & $1 \cdot 233$ & 995 & 0.33 \\
\hline \multirow{5}{*}{$\begin{array}{l}\text { High - pressure boilers } \\
\text { and public buildings. } \\
\text { Low - pressure boilers } \\
\text { and private houses... } \\
\text { Gas and coke plant } \ldots \\
\text { Metallurgical and other } \\
\text { furnaces ... ... ... }\end{array}$} & $7,316,257$ & 0.805 & 58,867 & i9.34 \\
\hline & $4,154,7$ & 0630 & 26,180 & 860 \\
\hline & $234,55 \mathrm{I}$ & & & - \\
\hline & $3,696,55^{\circ}$ & $5^{\circ} 291$ & I95.599 & $64 \cdot 26$ \\
\hline & $17,5^{82}, 5^{23}$ & I.808 & 304,391 & 100.00 \\
\hline
\end{tabular}

The author discusses the causes of imperfect combustion and the best means of ameliorating the output of smoke; but as these are generally well known and recognised, at least in theory, they need not be reproduced. That smoke abatement is nearly always an indirect means of effecting economy is another well-established fact to which he refers. Dr. Goss points out the interesting observation, which may not be generally known, that the visibility or otherwise of smoke has no direct relation to its content of solid matter. The adoption of anthracite coal or coke as fuel will serve to render the discharge less visible, but will not eliminate the emission of dust or fine cinder. He appears to think that the replacement of coal by electrical energy will not reduce the amount of visible smoke to any serious extent, for steam raising will still be necessary. The more extensive use of gaseous fuel, smoke-washing, and electrical precipitation of smoke as a means of smoke abatement are passed over, for some unexplained reason, as not within the scope of the paper.

The author is not very optimistic in his outlook, for he considers that a revolution in practice which will result in the elimination of existing sources of atmospheric pollution is not to be expected "because present-day knowledge is insufficient to supply the necessary means, and, second, because the immediate application to all sources of pollution, even of such means as are now available, is mechanically and financially impracticable."

If by this statement Dr. Goss includes all forms of atmospheric pollution such as arise from gaseous impurities and dust particles blown into the air from the streets, etc., no doubt he is right; but he has himself shown that gaseous impurities are minimal in quantity, because they are rapidly dispersed, whilst dust particles, which exist everywhere, have never been regarded as causing injury either to animal or plant life.

But the really harmful constituents of a town atmosphere are unequivocally derived from one sourcethe incomplete combustion of coal, and there are few people who have studied the question in this country who are not thoroughly convinced that the pressure of properly instructed and firm control, supported by adequate legal penalties and the force of intelligent public opinion, would rapidly diminish and eventually eliminate an evil for which no economic or, indeed, any other excuse can exist. We are throwing away in a wanton and criminal fashion, without let or hindrance, a valuable inheritance which should belong to coming generations, and which they will never be able to recover.

$$
\text { No. 2438, VOL. 97] }
$$

$M A N$ AS A MACHINE. 1

(I) A NUMBER of different experimental methods A for determining the respiratory exchange of man have been employed in the past, some of which are designed for long experiments and some for short, and of late years it has become evident that a critical examination ought to be made with the view of determining how far the different methods give trustworthy and comparable results. A comparison of this kind involves very great labour, and Dr. Carpenter is to be congratulated on having undertaken the work. His investigation is throughout characterised by that careful attention to detail that we have learnt to associate with the Nutrition Laboratory at Boston of the Carnegie Institution.

The experimental methods examined in detail are the bed respiration calorimeter described by Benedict and Carpento, two types of the Benedict universal respiration apparatus, and the apparatuses described by Zuntz and Geppert (the absence of the portable apparatus of Zuntz is perhaps a matter for regret), by Tissot and by Douglas. In addition, there is a description of accessory apparatus, including the Haldane gas analysis apparatus.

The experiments were made on resting subjects twelve hours or more after their last meal. In each experiment two of the different forms of apparatus were used either alternately or in series, the periods following each other as rapidly as possible. The three forms of Benedict apparatus were compared with one another, and the other methods were compared with the Benedict universal apparatus. Full tables of results are given, and these show that there is a wonderfully close agreement between the average figures obtained by the different methods.

In a critical discussion the author deals with the possible sources of error, as well as with the advantages and disadvantages of each of the methods.

In general comparable results can be obtained with all the methods investigated if care is taken, but preference is given to the Benedict apparatus, mainly on the ground that it is possible to obtain trustworthy results more quickly with it than with methods which involve volumetric gas analysis.

It would have lent additional interest to this discussion if a few comparative experiments could have been made during muscular work, as it is possible that some additional sources of error or inconvenience may become apparent when the different forms of apparatus are called upon to deal with a greatly increased respiratory exchange.

(2) The authors confine themselves in this publication to the calculation from the total respiratory exchange of the actual amount of energy liberated in the human body during walking exercise, but it is their intention to extend their observations in the future by means of direct calorimetry. An admirable introduction is afforded by an account of the previous history of the subject, amplified by an extensive table giving a complete summary of the results of previous observations.

The research has been conducted throughout in the laboratory on two athletic subjects. An ingenious form of horizontal treadmill is described, on which the subject walks at different paces, while the respiratory exchange is measured by means of the Benedict universal apparatus, various devices being employed for recording automatically the distance traversed, the number of steps taken, and the height through which the body is raised at each step. 1 (I) "A Comparison of Methods for Determining the Respiratory
Exchange of Man." By T. M. Carpenter. Pp. 265. (Publication No. 216 of the Carnegie Institution of Washington.) Price 2.50 dollars.

(2) "Energy Transformations during Horizontal Walking." liv F. G Renedict and $\mathrm{H}$. Murschbauser. Pp. $x \propto$. (Publication No. 23I of the Carnegie Institution of Wastington.) Price $\mathbf{x}$ dollar. 